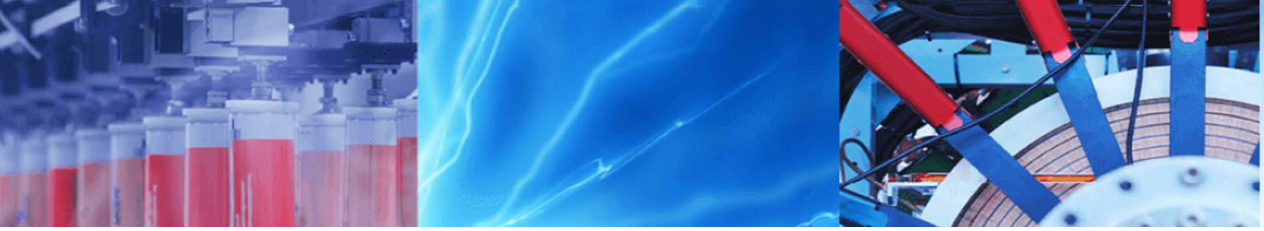

Research Article

\title{
Effect of drying on the essential oil traits and antioxidant potential $J$. regia L. leaves from Kumaun Himalaya
}

\author{
Lalit M. Tewari ${ }^{1} \cdot$ Lata Rana $^{2} \cdot$ Santosh K. Arya ${ }^{1} \cdot$ Geeta Tewari $^{2}$ D $\cdot$ Neha Chopra $^{1} \cdot$ Naveen C. Pandey $^{1} \cdot$ Penny Joshi $^{2}$. \\ Rekha Gahtori ${ }^{3}$
}

Received: 21 August 2019 / Accepted: 25 October 2019 / Published online: 12 November 2019

(c) Springer Nature Switzerland AG 2019

\begin{abstract}
Drying is an ancient technique adopted to reduce moisture, preserve aroma profile and increase the shelf life of the food products. During drying, the chemical, nutritional and antioxidant properties of the food can get altered as compared to the fresh material. Natural shade drying is the most accepted storage method for aromatic medicinal herbs because of its low cost and minimum loss of volatile constituents. In the present investigation, the effects of shade drying on the volatile components and antioxidant potential of walnut leaves (Juglans regia) have been studied. For this purpose, fresh walnut leaves were shade dried and hydrodistilled using Clevenger apparatus. The extracted oil was analysed by GC and GC/MS. The antioxidant potential of the oils was evaluated by 2, 2-diphenyl-1-picrylhydrazyl (DPPH.) radical scavenging activity. The GC and GC/MS analysis identified 46 and 42 compounds representing $89.29 \%$ and $96.38 \%$ of the total fresh and dried oils, respectively. The composition of the five major components namely $(E)$-caryophyllene, germacrene $D$, $a$-zingiberene, $\delta$-cadinene and $(E)$ - $\beta$-farnesene was observed to significantly increase after shade drying. Drying caused appearance of four components with complete loss of eight components. Fresh oil showed better antioxidant activity as compared to the shade dried oil.
\end{abstract}

Keywords Juglans regia · Essential oil · Drying $\cdot(E)$-caryophyllene $\cdot$ Germacrene D · Monoterpene $\cdot$ Antioxidant activity

\section{Introduction}

Juglans regia L., an aromatic indigenous plant of southeastern Europe, Asia, northern America, North Africa, India and China, belongs to the family Juglandaceae. It is commonly known as walnut "akhrot" (in Hindi) [1]. The essential oil of J. regia is an ingredient of dry skin creams, antiageing and anti-wrinkle products as it shows moisturizing properties along with free radical scavenging activity [2]. All the plant parts like green husks, leaves, green walnuts, bark and shells have been used in the pharmaceutical and cosmetic industries [3]. Highly nutritious seeds of the walnut tree are consumed as royal food across the globe.
These are rich in protein, carbohydrates, unsaturated fatty acids, vitamins, minerals (copper, iron, magnesium, phosphorus, potassium and sulphur) flavonoids, sterols, phenolic acids and fibres [4-6]. The stem bark of the plant is reported to show anthelmintic, astringent, bactericide, detergent, depurative, digestive, diuretic, insecticidal and laxative properties [7]. The leaves have been used as folk medicine due to their anthelmintic, astringent, antidiarrheic, fungicidal and insecticidal properties [4-6]. The oil is a rich source of $(E)$-caryophyllene, caryophyllene oxide, $\beta$-pinene, germacrene $D$ and carvacrol which are accountable for various biological activities.

Geeta Tewari, geeta_k@rediffmail.com | ${ }^{1}$ Department of Botany, D. S. B. Campus, Kumaun University, Nainital, India. ${ }^{2}$ Department of Chemistry, D. S. B. Campus, Kumaun University, Nainital, India. ${ }^{3}$ Department of Biotechnology, Bhimtal Campus, Kumaun University, Nainital, India. 
High demand of preserved and processed food products requires high-quality raw materials. Drying is a postharvest technique which is used for preservation, microbial decontamination, increase shelf life and disinfections of herbs [8]. It includes natural (sun, shade), hot air, microwave and freeze drying. Drying affects the content of flavour constituents of aromatic and medicinal plants which are considered as antioxidant and antimicrobial agents [9]. Drying may upgrade aroma quality of the plants either by esterification/oxidation/formation of new compounds or loss of volatile components [10]. A number of reports are available on the effect of drying on the essential oil composition of various aromatic species like Thymus vulgaris [11], Murraya koenigii [12], Ocimum americanum [13, 14], Ocimum gratissimum [15] and Origanum vulgare [16].

Reports are available on the volatile composition of $J$. regia leaves from Egypt [17], India [18-20], Tunisia [21], Iran [22] and the nuts from Pakistan [23]. There are few reports on the antioxidant potential evaluation of leaf oil of J. regia $[18,20,23]$.

Existing literature data revealed that no work has been reported on the effect of drying on the essential oil composition and antioxidant activity of J. regia leave oil. Therefore, the present work aims to explore the impact of natural shade drying on the aroma profile and antioxidant potential of J. regia L. oil from the Himalayan region of, Uttarakhand.

\section{Materials and methods}

\subsection{Collection of plant}

Fresh leaves of Juglans regia were collected from Padli, Ratighat (Bhowali), Nainital (Latitude: $29^{\circ} 23^{\circ} 410^{\prime} \mathrm{N}$; Longitude: $79^{\circ} 30^{\prime} 546^{\prime \prime} \mathrm{E}$; Altitude: $1700 \mathrm{~m}$ ) in the month of August 2017.

\subsection{Extraction of oil}

Two-kilogram fresh leaves of J. regia were subjected to hydrodistillation using Clevenger apparatus for 5 h. Five kilograms of fresh leaves were shade dried up to the constant weight and $500 \mathrm{~g}$ of dried material was hydrodistilled in Clevenger for $5 \mathrm{~h}$. The oils were dried over anhydrous sodium sulphate and kept in Biological Oxygen Demand (BOD) incubator at $4{ }^{\circ} \mathrm{C}$ prior to analysis.

\subsection{Analysis of oil}

The extracted oil was analysed on a Shimadzu 2010 GC, fitted with Rtx- 5 column $(30 \mathrm{~m} \times 0.25 \mathrm{~mm}$, i.d. $0.25 \mu \mathrm{m})$ and flame ionization detector (FID) using Nitrogen/air as the carrier gas. The column was programmed at $50{ }^{\circ} \mathrm{C}$ with a hold time of $2 \mathrm{~min}$ to $210^{\circ} \mathrm{C}$ at a rate of $3{ }^{\circ} \mathrm{C} / \mathrm{min}$ and increased to $280^{\circ} \mathrm{C}$ at $8{ }^{\circ} \mathrm{C} / \mathrm{min}$ rate and at $280^{\circ} \mathrm{C}$; the sample was hold for $16 \mathrm{~min}$. Nitrogen was adjusted at $30 \mathrm{~mL} /$ min column head pressure. The temperature of injector and FID was adjusted to $260^{\circ} \mathrm{C}$ and $270^{\circ} \mathrm{C}$, respectively. The split ratio was $1: 40$, and injection volume was $0.2 \mu \mathrm{L}$ neat oil. The GC/MS unit was GCMS-QP2010 Ultra consisted of Rtx- 5 column $(30 \mathrm{~m} \times 0.25 \mathrm{~mm}$, i.d. $0.25 \mu \mathrm{m})$. Helium was used as a carrier gas. The mass spectrum was recorded at $70 \mathrm{eV}$ and 40-650 amu. Conditions for GC/MS analysis were similar to that of GC.

\subsection{Identification of the components}

The identification of the individual constituent was done by comparing the fragmentation pattern of the mass spectral data with literature data [24] and by comparing with NIST (NIST version 2.1) and Wiley (7th edition) mass spectral database. The retention index (RI) of each constituent was calculated by comparing with $n$-alkane series $\left(C_{9}-C_{33}\right)$. The relative percentage of each compound in the oil was attained on the basis of FID response without using a correction factor.

\subsection{Antioxidant activity measurement}

The antioxidant potential of the oils was determined in terms of their radical scavenging activity by the bleaching of purple coloured methanolic solution of 2, 2-diphenyl1-picrylhydrazyl radical (DPPH) [25]. Ascorbic acid was used as standard. One $\mathrm{mL}$ solution of oil and standard comprising of different concentrations in methanol $(50,100,200,400$, $800,1000 \mu \mathrm{g} / \mathrm{mL}$ for fresh oil; $10,20,40,80,160 \mathrm{mg} / \mathrm{mL}$ for dry oil and 10, 20, 40, 80, $160 \mu \mathrm{g} / \mathrm{mL}$ for ascorbic acid) were mixed with $5 \mathrm{~mL}$ methanolic solution of DPPH (0.2 mM). A control was also run without oil under similar conditions. All the samples were incubated for $30 \mathrm{~min}$ in the dark at room temperature. The test was performed in triplicate, and the data were represented as mean \pm standard deviation (SD) values. The DPPH radical scavenging effect was calculated as "percentage inhibition" according to the equation:

$\%$ DPPH scavenging activity $=\frac{\left(A_{\mathrm{o}}-A_{\mathrm{t}}\right)}{A_{\mathrm{o}}} \times 100$

where $A_{\mathrm{o}}$ is the absorbance of control sample at $517 \mathrm{~nm}$ and $A_{\mathrm{t}}$ is the absorbance value of oil at $517 \mathrm{~nm}$.

\subsection{Statistical analysis}

All the analysis of the present study was carried out in triplicate, and the mean \pm SD was calculated by MS Excel. Two-tailed paired $t$ test was performed to compare mean 
content of major essential oil constituents of fresh and dried J. regia leaves using MS Excel at probability level of $p<0.05$ and $p<0.01$. The data were subjected to one-way ANOVA to evaluate significant difference between different treatment groups (significance level of $p<0.05$ ).

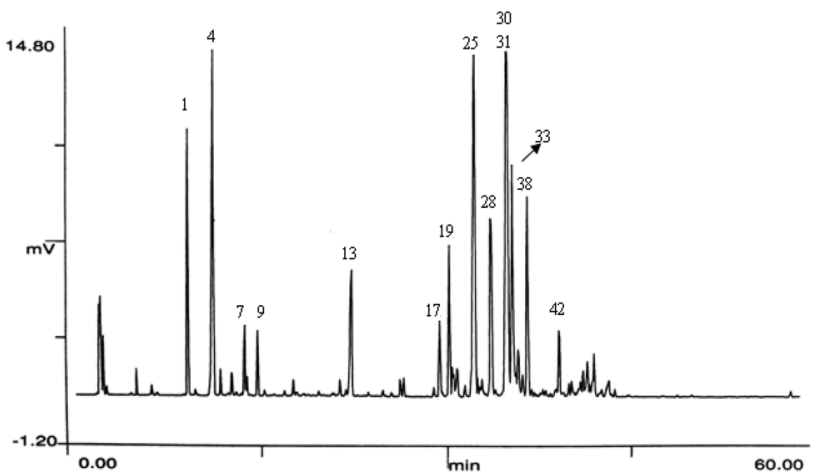

Fig. 1 Gas chromatogram of fresh J. regia oil

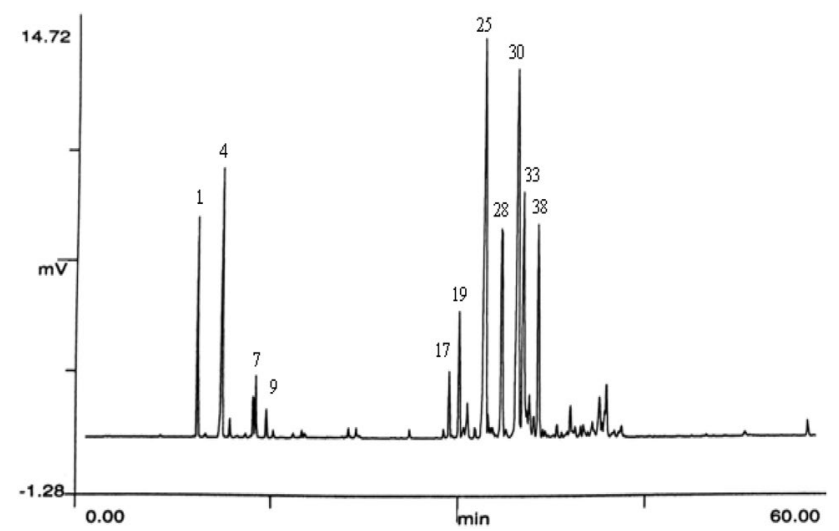

Fig. 2 Gas chromatogram of dried J. regia oil

\section{Results and discussion}

\subsection{Essential oil composition}

A total of 46 and 42 compounds were identified on the basis of GC (Figs. 1, 2) and GC/MS analysis which represented $89.29 \%$ and $96.38 \%$ of the total fresh and dried oils, respectively. The essential oil yield was $0.02 \%(\mathrm{v} / \mathrm{w})$. The major components in the fresh leave oil of J. regia were $(E)$-caryophyllene (13.30\%), $\beta$-pinene $(11.63 \%)$, germacrene $D(9.31 \%), \beta$-selinene (7.77\%), $\alpha$-zingiberene (6.74\%), a-pinene (6.22\%) and $\delta$-cadinene (5.38\%) (Table 1; Fig. 3).

Previous study on $J$. regia fresh leaf oil from Indian Western Himalaya also reported the high percentage of $(E)$-caryophyllene, $\beta$-pinene, germacrene $D$ and $\alpha$-zingiberene [19] (Table 1; Fig. 4). Another report on the leaf essential oil of J. regia from USA suggested the presence of germacrene $D$ and methyl salicylate as major constituents [17]. Furthermore, the leaf essential oil from Kashmiri akhrot was predominated by $\beta$-pinene, $a$-pinene, $\beta$-caryophyllene and germacrene $D$ [18]. A previous study from Pakistan reported the high percentage of benzyl alcohol, nerolidol, globulol and p-cymene in the nuts oil of J. regia. Moravej et al. [22] examined the essential oil composition of walnut hydrosol from Iran and observed the composition to be entirely different from leaf oil. The main components of the hydrosol oil were oxygenated monoterpenes such as thymol and carvacrol (Table 1).

In the present study, the major volatile components in the shade dried oil were $(E)$-caryophyllene (18.88\%), germacrene $D(18.53 \%)$, a-zingiberene $(9.88 \%), \beta$-pinene $(8.27 \%),(E)-\beta$-farnesene $(7.73 \%), \delta$-cadinene $(6.81 \%)$ and a-pinene (5.04\%). In a previous report from Tunisia [21], caryophyllene oxide, $(E)$-caryophyllene, germacrene $\mathrm{D}$ and $\beta$-pinene were obtained as major components in the shade dried J. regia leaf oil (Table 1; Fig. 4). Eight components including camphene, (3E)-hexenyl acetate, methyl salicylate, bornyl acetate, $\beta$-selinene, trans-muurola-4(14),

Table 1 Previous reports on J. regia essential oil

\begin{tabular}{|c|c|c|c|c|}
\hline S. no. & Collection site & Plant part & Major constituents & References \\
\hline 1. & Kentucky, USA & Leaf & Germacrene D (28.6\%) and methyl salicylate (16.8\%) & [17] \\
\hline 2. & Kashmir & Leaf & $\begin{array}{l}\beta \text {-Pinene }(30.5 \%) \text {, a-pinene (15.1\%), } \beta \text {-caryophyllene (15.5\%) and germac- } \\
\text { rane } D(14.4 \%)\end{array}$ & [18] \\
\hline 3. & India (Western Himalaya) & leaf & $\begin{array}{l}\text { (E)-Caryophyllene (47.9\%), } \beta \text {-pinene (39.5\%), germacrene D }(23.3 \%) \text {, } \\
\text { a-pinene (18.1\%), a-humulene (11.8\%), a-zingiberene (11.3\%), a-copaene } \\
\text { (10.1\%), limonene (8.6\%), caryophyllene oxide (8.6\%), ar-curcumene } \\
(7.2 \%), \delta \text {-cadinene }(6.7 \%),(E) \text { - } \beta \text {-farnesene }(5.9 \%) \text { and 1,8-cineole }(5.4 \%)\end{array}$ & [19] \\
\hline 4. & Tunisia & Leaf & $\begin{array}{l}\text { Caryophyllene oxide ( } 27.4 \%) \beta \text {-caryophyllene }(22.5 \%) \text {, germacrene D } \\
(9.4 \%) \text { and } \beta \text {-pinene }(9.5 \%)\end{array}$ & [21] \\
\hline 5. & Iran & Walnut hydrosol & Carvacrol (33.21\%), thymol (16\%) and homoveratrole (15.83\%) & [22] \\
\hline 6. & Pakistan & Nuts oil & $\begin{array}{l}\text { Benzyl alcohol (18.14\%), nerolidol (13.54\%), globulol (10.95\%) and } \\
\text { p-cymene (10.94\%) }\end{array}$ & [23] \\
\hline
\end{tabular}


5-diene, a-bulnesene and elemol were present only in fresh oil. Out of these, $\beta$-selinene was present as major component. In addition, a-terpineol, spathulenol, globulol and salvia-4(14)-en-1-one were present only in the dried sample. The mean percentage of six components namely $\beta$-pinene $(11.63-8.27 \%$ at $p<0.05), \beta$-selinene (7.77-0.00\%), a-pinene $(6.22-5.04 \%$ at $p<0.05)$, methyl salicylate $(4.02-0.00 \%)$, caryophyllene oxide (1.56-0.84\% at $p<0.01)$ and 1,8 -cineole $(1.47-1.15 \%$ at $p<0.01)$ significantly decreased on drying. It was observed that drying led to the significant increase in the percentage of five major compounds including $(E)$-caryophyllene $(13.30-18.88 \%$ at $p<0.01)$, germacrene $D(9.31-18.53 \%$ at $p<0.01)$, a-zingiberene $(6.74-9.88 \%$ at $p<0.01), \delta$-cadinene $(5.38-6.81 \%$ at $p<0.05)$ and $(E)-\beta$-farnesene $(4.57-7.73 \%$ at $p<0.05$ ). Four common constituents present in less than $0.20 \%$ amount were neryl acetate $(0.02-0.04 \%)$, linalool $(0.06-0.14 \%), \beta$-sesquiphellandrene $(0.09-0.12 \%)$ and a-cubebene $(0.16-0.19 \%)$ (Table 1). The present study identified $\beta$-selinene (7.77\%), a-bisabolol (0.99\%), geranyl acetate $(0.57 \%), 2$-undecanone $(0.36 \%), \beta$-gurjunene $(0.29 \%)$, humulene epoxide II $(0.23 \%), 1,10$-di-epi-Cubenol $(0.25 \%)$ and 1 -epi-cubenol $(0.17 \%)$ in significant amount for the first time in the dried oil of $J$. regia.

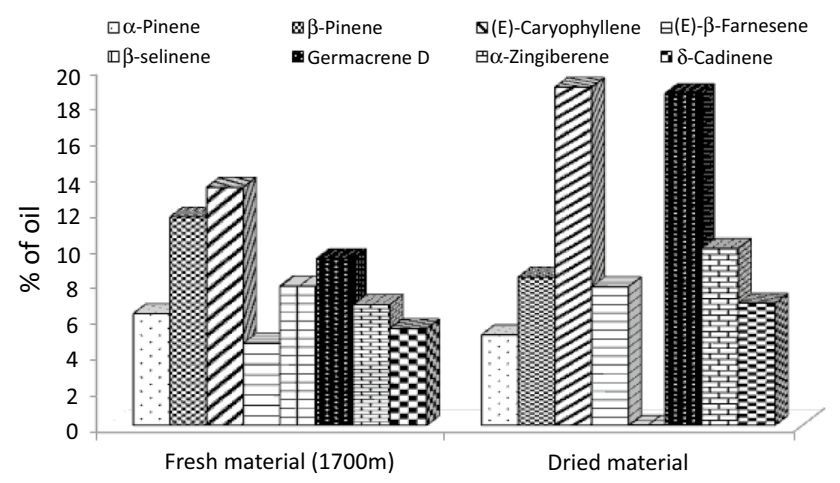

Fig. 3 Variation in the major constituents of fresh and dried J. regia
Sesquiterpene hydrocarbon was the predominating class of volatile compounds in the fresh and dried oil collected from Bhowali (Fig. 5). The result was in good agreement with those obtained by Verma et al. [19]. Kashmiri akhrot oil was rich in monoterpene hydrocarbons (a-pinene and $\beta$-pinene) and sesquiterpene hydrocarbons ( $\beta$-caryophyllene and germacrene $D)$ [18]. Furthermore, the oil from Tunisia was found to be rich in oxygenated sesquiterpene (caryophyllene oxide) and sesquiterpene hydrocarbon ( $\beta$-caryophyllene) [21] (Fig. 6). The difference in the percentage of the compounds depends upon environmental (seasonal, geographical, climatic), genetic factors, distillation and post-harvest technique (drying, storage conditions) $[12-15,26]$

\subsection{Antioxidant activity}

The DPPH radical scavenging activity of $J$. regia leaf oils and standard (ascorbic acid) is shown in Tables 2, 3 and Table 4. The results revealed that the samples exhibited concentration-dependent DPPH radical scavenging activity. The antioxidant activity of the fresh oil $\left(\mathrm{IC}_{50}: 923.49 \mu \mathrm{g} /\right.$ $\mathrm{mL}$ ) was found to be ten times less than the standard ( $\mathrm{IC}_{50}$ $(92.78 \mu \mathrm{g} / \mathrm{mL})($ Tables 3,5$)$. The results were in good agreement with the previous report on Ocimum gratissimum in which the fresh oil showed better DPPH radical scavenging activity as compared to the dried oil [15]. The dried oil showed moderate antioxidant activity with $\mathrm{IC}_{50}$ value of $48.77 \mathrm{mg} / \mathrm{mL}$ (Table 4). Similar to the present study, fresh material of Camellia sinensis was observed to have higher antioxidant content as compared to the dried plant material. This could be attributed degradation caused by the process of drying [27]. On the contrary, study by Pinela et al. has shown that the dried plant material has higher antioxidant content than the fresh plant material [28].

The $\mathrm{IC}_{50}$ value of fresh J. regia oil from Kashmir was $34.5 \mu \mathrm{g} / \mathrm{mL}$ [18]. The compounds present in the Kashmiri

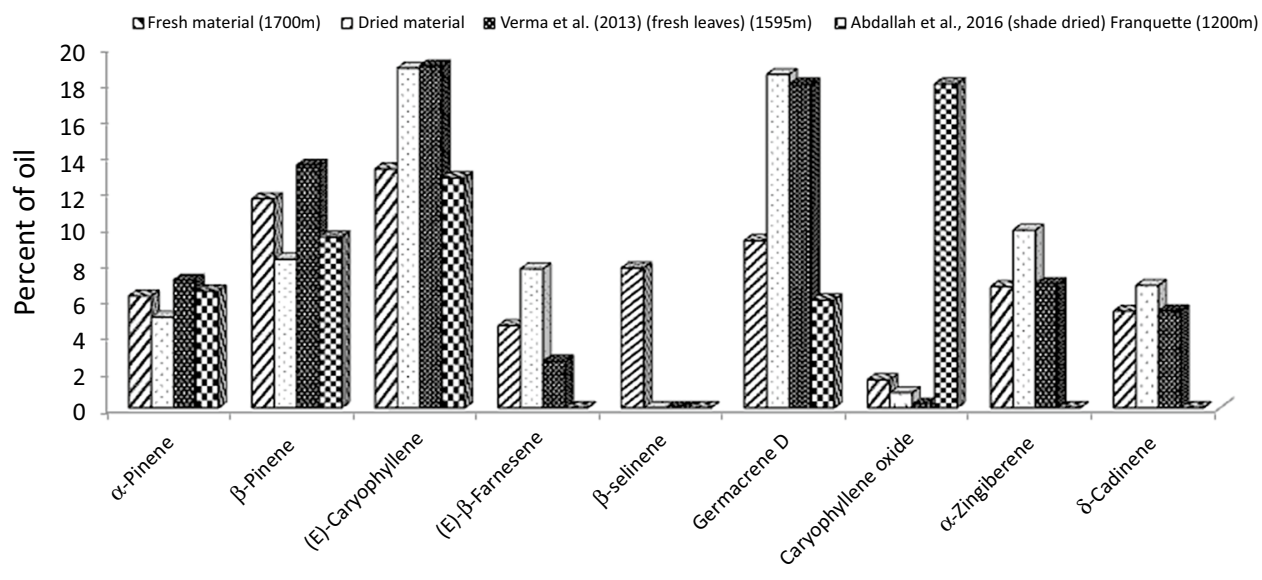

Fig. 4 Comparative essential oil composition of J. regia oil 
Fig. 5 Variation in the class of terpenoids in fresh and dried J. regia

Fig. 6 Comparative class of compounds in J. regia
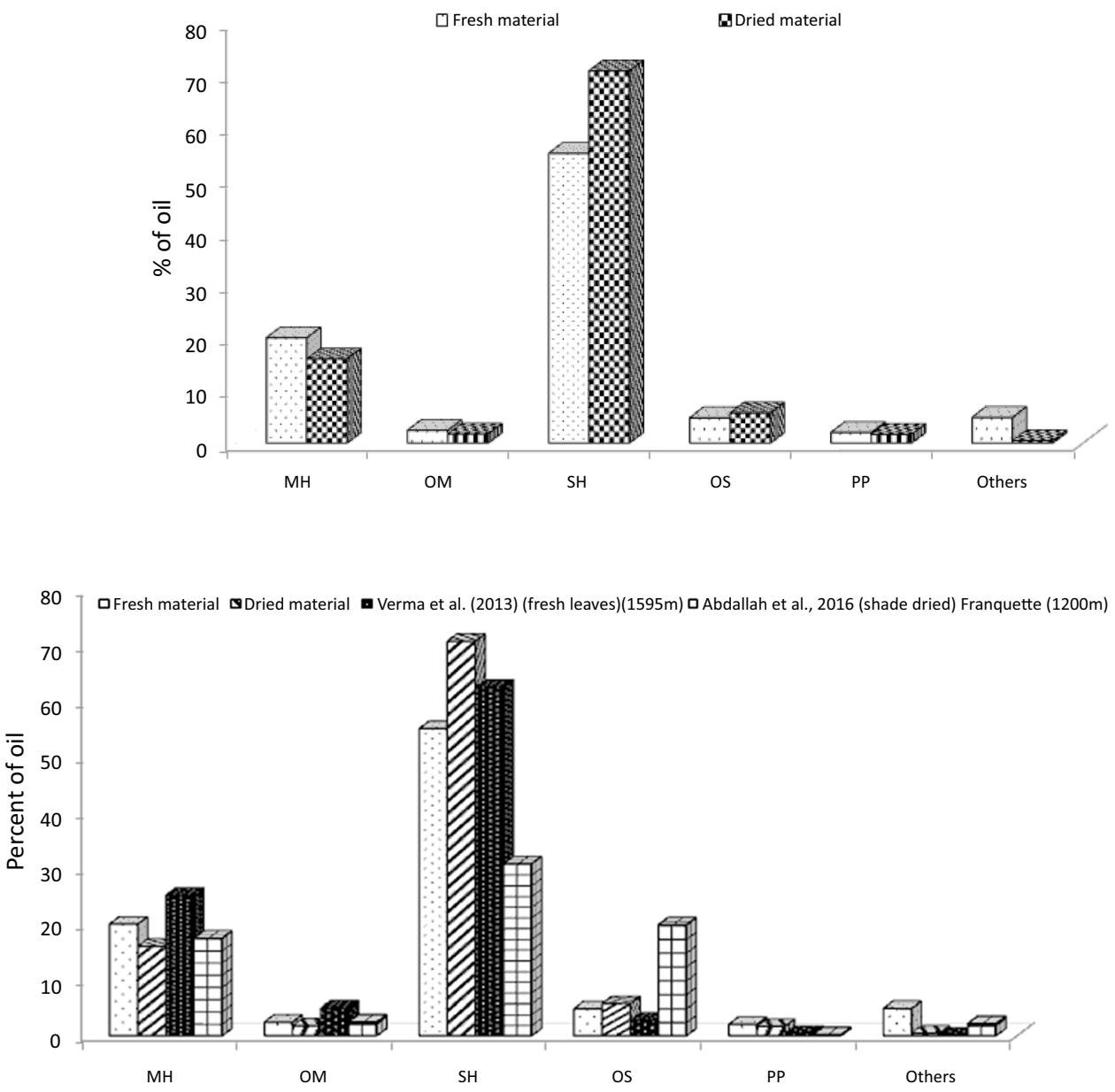
Table 2 Variation in the essential oil composition of fresh and dried J. regia

\begin{tabular}{|c|c|c|c|c|c|c|c|}
\hline S. no. & $\begin{array}{l}\text { Calculated } \\
\text { retention } \\
\text { index }\end{array}$ & $\begin{array}{l}\text { Retention } \\
\text { index [24] }\end{array}$ & Name of component & $\begin{array}{l}\text { Retention time of } \\
\text { components in } \\
\text { fresh Juglans regia } \\
\text { leaves (minutes) }\end{array}$ & $\begin{array}{l}\text { Mean per } \\
\text { cent } \pm \text { SD (fresh } \\
\text { Juglans regia } \\
\text { leaves) }\end{array}$ & $\begin{array}{l}\text { Retention time } \\
\text { (GC) of compo- } \\
\text { nents in dried Jug- } \\
\text { lans regia leaves } \\
\text { (minutes) }\end{array}$ & $\begin{array}{l}\text { Mean per cent } \pm \text { SD } \\
\text { (dried Juglans regia } \\
\text { leaves) }\end{array}$ \\
\hline 1. & 929 & 932 & a-Pinene & 9.19 & $6.22 \pm 0.26$ & 9.17 & $5.04^{*} \pm 0.44$ \\
\hline 2. & 945 & 946 & Camphene & 9.78 & 0.07 & - & ND \\
\hline 3. & 969 & 969 & Sabinene & 10.93 & 0.14 & 10.97 & 0.47 \\
\hline 4. & 974 & 974 & $\beta$-Pinene & 11.21 & $11.63 \pm 0.92$ & 11.17 & $8.27^{*} \pm 0.31$ \\
\hline 5. & 987 & 988 & Myrcene & 11.77 & $0.48 \pm 0.14$ & 11.78 & 0.40 \\
\hline 6. & 1003 & 1001 & (3E)-Hexenyl acetate & 12.66 & 0.49 & - & ND \\
\hline 7. & 1029 & 1026 & 1,8-Cineole & 13.70 & $1.47 \pm 0.06$ & 13.68 & $1.15^{* *} \pm 0.05$ \\
\hline 8. & 1044 & 1044 & (E)- $\beta$-Ocimene & 13.89 & $0.29 \pm 0.01$ & 13.88 & $1.25^{* *} \pm 0.09$ \\
\hline 9. & 1082 & 1086 & Terpinolene & 14.75 & $1.19 \pm 0.33$ & 14.73 & $0.58 \pm 0.10$ \\
\hline 10. & 1099 & 1095 & Linalool & 15.27 & 0.06 & 15.28 & 0.14 \\
\hline 11. & 1178 & 1174 & Terpinen-4-ol & 21.34 & 0.24 & 21.31 & 0.17 \\
\hline 12. & 1185 & 1186 & a-Terpineol & - & ND & 21.94 & 0.17 \\
\hline 13. & 1190 & 1190 & Methyl salicylate & 22.29 & $4.02 \pm 0.17$ & - & ND \\
\hline 14. & 1281 & 1284 & Bornyl acetate & 25.50 & 0.06 & - & ND \\
\hline 15. & 1291 & 1293 & 2-Undecanone & 26.22 & $0.36 \pm 0.10$ & 26.20 & $0.17 \pm 0.01$ \\
\hline 16. & 1344 & 1345 & a-Cubebene & 28.94 & 0.16 & 28.91 & 0.19 \\
\hline 17. & 1350 & 1356 & Eugenol & 29.47 & $2.01 \pm 0.09$ & 29.40 & $1.65 \pm 0.18$ \\
\hline 18. & 1357 & 1359 & Neryl acetate & 29.58 & 0.04 & 29.56 & 0.02 \\
\hline 19. & 1373 & 1374 & a-Copaene & 30.24 & $3.71 \pm 0.26$ & 30.18 & $3.54 \pm 0.05$ \\
\hline 20. & 1377 & 1379 & Geranyl acetate & 30.46 & 0.57 & 30.43 & 0.10 \\
\hline 21. & 1379 & 1387 & $\beta$-Cubebene & 30.57 & 0.35 & 30.53 & 0.18 \\
\hline 22. & 1386 & 1389 & $\beta$-Elemene & 30.85 & $0.84 \pm 0.05$ & 30.82 & $1.07 \pm 0.06$ \\
\hline 23. & 1401 & 1390 & 7-epi-Sesquithujene & 31.46 & 0.18 & 31.44 & 0.24 \\
\hline 24. & 1411 & 1411 & (Z)-a-Bergamotene & 31.96 & 0.29 & 31.94 & 0.35 \\
\hline 25. & 1417 & 1417 & (E)-Caryophyllene & 32.33 & $13.30 \pm 0.26$ & 32.30 & $18.88^{* *} \pm 0.92$ \\
\hline 26. & 1425 & 1430 & $\beta$-Copaene & 32.51 & 0.28 & 32.49 & 0.43 \\
\hline 27. & 1432 & 1431 & $\beta$-Gurjunene & 32.85 & 0.29 & 32.82 & 0.24 \\
\hline 28. & 1453 & 1454 & $(E)$ - $\beta$-Farnesene & 33.59 & $4.57 \pm 0.31$ & 33.56 & $7.73^{*} \pm 0.87$ \\
\hline 29. & 1473 & 1478 & Y-Muurolene & 33.64 & 0.02 & 33.64 & 0.70 \\
\hline 30. & 1479 & 1484 & Germacrene D & 34.89 & $9.31 \pm 0.60$ & 34.94 & $18.53^{* *} \pm 1.01$ \\
\hline 31. & 1485 & 1489 & $\beta$-Selinene & 35.01 & $7.77 \pm 0.20$ & - & ND \\
\hline 32. & 1488 & 1493 & $\begin{array}{l}\text { trans-Muurola- } 4(14), 5- \\
\text { diene }\end{array}$ & 35.11 & 0.07 & - & ND \\
\hline 33. & 1494 & 1493 & a-Zingiberene & 35.39 & $6.74 \pm 0.67$ & 35.37 & $9.88^{* *} \pm 0.34$ \\
\hline 34. & 1498 & 1505 & $(E, E)$-a-Farnesene & 35.82 & $1.29 \pm 0.29$ & 35.79 & $1.32 \pm 0.16$ \\
\hline 35. & 1505 & 1509 & a-Bulnesene & 35.97 & 0.05 & - & ND \\
\hline 36. & 1509 & 1513 & $\gamma$-Cadinene & 36.14 & 0.46 & 36.13 & 0.63 \\
\hline 38. & 1516 & 1521 & $\beta$-Sesquiphellandrene & 36.89 & 0.09 & 36.87 & 0.12 \\
\hline 39. & 1521 & 1522 & $\delta$-Cadinene & 36.57 & $5.38 \pm 0.13$ & 36.53 & $6.81^{*} \pm 0.27$ \\
\hline 40. & 1545 & 1548 & Elemol & 37.08 & 0.10 & - & ND \\
\hline 41. & 1559 & 1561 & (E)-Nerolidol & 38.00 & 0.09 & 37.99 & 0.32 \\
\hline 42. & 1573 & 1577 & Spathulenol & - & ND & 38.38 & 0.09 \\
\hline 43. & 1576 & 1582 & Caryophyllene oxide & 39.13 & $1.56 \pm 0.10$ & 39.07 & $0.84^{* *} \pm 0.05$ \\
\hline 44. & 1581 & 1590 & Globulol & - & ND & 39.25 & 0.05 \\
\hline 45. & 1587 & 1594 & Salvial-4(14)-en-1-one & - & ND & 39.46 & 0.28 \\
\hline 46. & 1603 & 1608 & Humulene epoxide II & 39.90 & 0.23 & 39.89 & 0.22 \\
\hline 47. & 1611 & 1618 & 1,10-di-epi-Cubenol & 40.13 & 0.25 & 40.11 & 0.23 \\
\hline
\end{tabular}


Table 2 (continued)

\begin{tabular}{|c|c|c|c|c|c|c|c|}
\hline S. no. & $\begin{array}{l}\text { Calculated } \\
\text { retention } \\
\text { index }\end{array}$ & $\begin{array}{l}\text { Retention } \\
\text { index [24] }\end{array}$ & Name of component & $\begin{array}{l}\text { Retention time of } \\
\text { components in } \\
\text { fresh Juglans regia } \\
\text { leaves (minutes) }\end{array}$ & $\begin{array}{l}\text { Mean per } \\
\text { cent } \pm \text { SD (fresh } \\
\text { Juglans regia } \\
\text { leaves) }\end{array}$ & $\begin{array}{l}\text { Retention time } \\
\text { (GC) of compo- } \\
\text { nents in dried Jug- } \\
\text { lans regia leaves } \\
\text { (minutes) }\end{array}$ & $\begin{array}{l}\text { Mean per cent } \pm \text { SD } \\
\text { (dried Juglans regia } \\
\text { leaves) }\end{array}$ \\
\hline 48. & 1623 & 1627 & 1-epi-Cubenol & 40.83 & 0.17 & 40.81 & 0.64 \\
\hline 49. & 1640 & 1644 & a-Muurolol & 41.06 & 0.51 & 41.01 & 0.04 \\
\hline 50. & 1652 & 1652 & a-Cadinol & 41.40 & $0.90 \pm 0.10$ & 41.41 & $1.57 \pm 0.06$ \\
\hline 51. & 1684 & 1685 & a-Bisabolol & 41.94 & $0.99 \pm 0.09$ & 41.95 & $1.68^{* *} \pm 0.17$ \\
\hline Total & & & & - & 89.29 & - & 96.38 \\
\hline
\end{tabular}

ND, Not detected

Mean values \pm SD (standard deviation) followed by ${ }^{* *}$ and ${ }^{*}$ indicated significance difference between pairs (fresh and dried) at $p<0.01$ and $p<0.05$, respectively

Table 3 Antioxidant activity of J. regia fresh oil

\begin{tabular}{lcc}
\hline S. no. & Oil concentration $(\mu \mathrm{g} / \mathrm{mL})$ & $\%$ Inhibition $\pm S D$ \\
\hline 1 & 50 & $13.77^{\mathrm{a}} \pm 0.41$ \\
2 & 100 & $16.04^{\mathrm{b}} \pm 0.30$ \\
3 & 200 & $18.39^{\mathrm{c}} \pm 0.31$ \\
4 & 400 & $23.98^{\mathrm{d}} \pm 0.35$ \\
5 & 800 & $47.14^{\mathrm{e}} \pm 0.31$ \\
6 & 1000 & $53.29^{\mathrm{f}} \pm 0.40$ \\
$\mathrm{IC}_{50}$ & & $923.49 \mu \mathrm{g} / \mathrm{mL}$ \\
\hline
\end{tabular}

The mean values followed by different alphabets $(a-f)$ at superscript are significantly different at $p<0.05$ according to Duncan's Test

Table 4 Antioxidant activity of dried J. regia oil

\begin{tabular}{lcc}
\hline S. no. & $\begin{array}{l}\text { Concentration }(\mathrm{mg} / \\
\mathrm{mL})\end{array}$ & \% Inhibition by oil $\pm \mathrm{SD}$ \\
\hline 1 & 10 & $26.73^{\mathrm{a}} \pm 0.87$ \\
2 & 20 & $40.35^{\mathrm{b}} \pm 0.56$ \\
3 & 40 & $57.37^{\mathrm{c}} \pm 0.33$ \\
4 & 80 & $66.43^{\mathrm{d}} \pm 0.60$ \\
5 & 160 & $80.43^{\mathrm{e}} \pm 0.40$ \\
$\mathrm{IC}$ & & $48.77 \mathrm{mg} / \mathrm{mL}$ \\
\hline
\end{tabular}

The mean values followed by different alphabets (a-e) at superscript are significantly different at $p<0.05$ according to Duncan's Test

Juglans were also present in our collection in significant amounts. Some authors have observed the antioxidant properties of monoterpenes in essential oils. The antioxidant potential of Retama raetam oil could be attributed to the relatively high percentage of monoterpenes [29]. Rather et al. [18] reported that the antimicrobial and antioxidant activity of $J$. regia could be attributed to the synergetic effect of the bioactive constituents. The antioxidant
Table 5 Antioxidant activity of ascorbic acid

\begin{tabular}{lcc}
\hline S. no. & Concentration $(\mu \mathrm{g} / \mathrm{mL})$ & $\begin{array}{l}\% \text { Inhibition by } \\
\text { ascorbic acid } \pm S D\end{array}$ \\
\hline 1 & 10 & $4.78^{\mathrm{a}} \pm 0.48$ \\
2 & 20 & $27.33^{\mathrm{b}} \pm 0.15$ \\
3 & 40 & $38.61^{\mathrm{C}} \pm 0.17$ \\
4 & 80 & $47.45^{\mathrm{d}} \pm 0.43$ \\
5 & 160 & $72.73^{\mathrm{e}} \pm 0.25$ \\
$\mathrm{IC}_{50}$ & & $92.78 \mu \mathrm{g} / \mathrm{mL}$ \\
\hline
\end{tabular}

The mean values followed by different alphabets (a-e) at superscript are significantly different at $p<0.05$ according to Duncan's Test

capacity of Schinus molle L. could be explained by the presence of monoterpenes ( $\beta$-carotine) [30].

\section{Conclusion}

From the study, it can be concluded that drying has impact on the essential oil composition, number of components and the antioxidant potential of J. regia. The plant could be a potential natural resource for high value aroma chemicals such as $(E)$-caryophyllene, germacrene $D, \beta$-pinene, $\beta$-selinene and $\alpha$-zingiberene. The results showed that the shade drying of $J$. regia decreased its antioxidant power.

Acknowledgements The authors are grateful to the IERP, GBPNIHSED, Kosi, Karmal (Grant No. GBPI/IERP-NMHS/15-16/48) for financial assistance and The Head, Department of Botany, Kumaun University Nainital for providing necessary laboratory facilities. 


\section{Compliance with ethical standards}

Conflict of interest The authors declare that they have no conflict of interest.

\section{References}

1. Tsamouris G, Hatziantoniou S, Demetzos C (2002) Lipid analysis of Greek Walnut oil (Juglans regia L.). Z Naturforschung 57c:51-56. https://doi.org/10.1515/znc-2002-1-209

2. Espin JC, Soler-Rivas C, Wichers HJ (2000) Characterization of the total free radical scavenger capacity of vegetable oils and oil fractions using 2,2-di-phenyl- 1-picrylhydrazyl radical. J Agric Food Chem 48(3):648-656. https://doi.org/10.1021/jf9908188

3. Oliveira I, Sousa A, Ferreira I, Bento A, Estevinho L, Pereira JA (2008) Total phenols, antioxidant potential and antimicrobial activity of walnut (Juglans regia L.) green husks. Food Chem Toxicol 46(7):2326-2331. https://doi.org/10.1016/j.fct.2008.03.017

4. Prasad RBN (2003) Walnuts and pecans. In: Caballero B, Trugo LC, Finglas PM (eds) Encyclopaedia of food sciences and nutrition. Academic Press, London, pp 6071-6079

5. Labuckas DO, Maestri DM, Perello M, Martinez ML, Lamarque AL (2008) Phenolics from walnut (Juglans regia L.) kernels: antioxidant activity and inter-actions with proteins. Food Chem 107(2):607-612. https://doi.org/10.1016/j.foodc hem.2007.08.051

6. Pereira JA, Oliveira I, Sousa A, Ferreira I, Bento A, Estevinho L (2008) Bioactive properties and chemical composition of six walnut (Juglans regia L.) cultivars. Food Chem Toxicol 46(6):21032111. https://doi.org/10.1016/j.fct.2008.02.002

7. Chopra RN, Nayar SL, Chopra RC (1986) Glossary of Indian medicinal plants (including the supplement). New Delhi, Council of Scientific and Industrial Research, p 11

8. Sourestani MM, Malekzadeh M, Tava A (2014) Influence of drying, storage and distillation times on essential oil yield and composition of anise hyssop Agastache foeniculum (Pursh.) Kuntze. J Essent Oil Res 26:177-184. https://doi.org/10.1080/10412 905.2014.882274

9. Capecka E, Mareczek A, Leja M (2005) Antioxidant activity of fresh and dry herbs of some Lamiaceae species. Food Chem 93(2):223-226. https://doi.org/10.1016/j.foodc hem.2004.09.0120

10. Hossain MB, Barry-Ryan C, Martin-Diana AB, Brunton NP (2010) Effect of drying method on the antioxidant capacity of six Lamiaceae herbs. Food Chem 123(1):85-91. https://doi.org/10.1016/j. foodchem.2010.04.003

11. Calín-Sánchez Á, Figiel A, Lech K, Szumny A, Carbonell-Barrachina ÁA (2013) Effects of drying methods on the composition of thyme (Thymus vulgaris L.) essential oil. Dry Technol 31(2):224-235. https://doi.org/10.1080/07373937.2012.725686

12. Rani A, Bisht M, Pande C, Tewari G, Bhatt S, Matiyani M (2017) Effect of drying on the volatiles of leaves of Murraya koenigii (L.). J Essent Oil Bear Plant 20(2):552-558. https://doi. org/10.1080/0972060X.2017.1317606

13. Bhatt S, Tewari G, Pande C, Rana L (2018) Impact of drying methods on essential oil composition of Ocimum americanum L. from Kumaun Himalayas. J Essent Oil Bear Plant 21(5):1385-1396. https://doi.org/10.1080/0972060X.2018.1543031
14. Bisht M, Rana L, Tewari G, Pande C, Bhatt S (2019) Effect of natural drying methods on flavour profile of camphor rich Ocimum americanum L. from North India. Asian J Chem 31(2):1321-1326. https://doi.org/10.14233/ajchem.2019.21862

15. Bhatt S, Bisht M, Tewari G, Pande C, Prakash O, Rana L (2019) Evaluation of antioxidant potential and quality of volatile constituents of fresh and sun dried Ocimum gratissimum. J Indian Chem Soc 96:297-304

16. Bhatt S, Tewari G, Pande C, Prakash O, Tripathi S (2019) Aroma profile and antioxidant potential of Origanum vulgare L.: impact of drying. J Essent Oil Bear Plant 22(1):214-230. https://doi. org/10.1080/0972060X.2019.1599736

17. Farag MA (2008) Headspace analysis of volatile compounds in leaves from the Juglandaceae (Walnut) family. J Essent Oil Res 20(4):323-327. https://doi.org/10.1080/10412905.2008.97000 23

18. Rather MA, Dar BA, Dar MY, Wani BA, Shah WA, Bhat BA, Ganai BA, Bhat KA, Anand R, Qurishi MA (2012) Chemical composition, antioxidant and antibacterial activities of the leaf essential oil of Juglans regia L. and its constituents. Phytomedicine (15) 19(13):1185-1190. https://doi.org/10.1016/j.phyme d.2012.07.018

19. Verma RS, Padalia RC, Chauhan A, Thul ST (2013) Phytochemical analysis of the leaf volatile oil of walnut tree (Juglans regia L.) from western Himalaya. Ind Crop Prod 42:195-201. https://doi. org/10.1016/j.indcrop.2012.05.032

20. Shah TI, Sharma E, Ahmad G (2014) Juglans regia Linn. A phytopharmacological review. World J Pharm Sci 2(4):363-373

21. Abdallah IB, Baatour O, Mechrgui K, Herchi W, Albouchi A, Chalghoum A, Boukhchina S (2016) Essential oil composition of walnut tree (Juglans regia L.) leaves from Tunisia. J Essent Oil Res 28(6):545-550. https://doi.org/10.1080/10412905.2016.1166157

22. Moravej H, Salehi A, Razavi Z, Moein MR, Etemadfard H, Karami F, Ghahremani F (2016) Chemical composition and the effect of walnut hydrosol on glycemic control of patients with type 1 diabetes. Int J Endocrinol Metab 14(1):e34726. https://doi. org/10.5812/ijem.34726

23. Abbasi MA, Raza A, Riaz T, Shahzadi T, Rehman A, Jahangir M, Shahwar D, Siddiqui SZ, Chaudhary AR, Ahmad N (2010) Investigation on the volatile constituents of Juglans regia and their in vitro antioxidant potential. Proc Pak Acad Sci 47(3):137-141

24. Adams RP (2007) Identification of essential oil components by gas chromatography/mass spectrometry. Allured Publishing Corp, Carol Stream

25. Singh G, Marimuthu P, Murali HS, Bawa AS (2005) Antioxidative and antibacterial potential of the essential oils and extract isolated from various spices material. J Food Saf 25(2):130-145. https://doi.org/10.1111/j.1745-4565.2005.00564.x

26. Singh S, Tewari G, Pande C, Singh C (2013) Variation in essential oil composition of Ocimum americanum L. from Kumaun northwestern Himalayan region. J Essent Oil Res 25(4):278-290. https ://doi.org/10.1080/10412905.2013.775079

27. Pinela J, Barros L, Duenas M, Carvalho AM, Santos-Buelga $C$, Ferreira IC (2012) Antioxidant activity, ascorbic acid, phenolic compounds and sugars of wild and commercial Tuberaria lignosa samples: effects of drying and oral preparation methods. Food Chem 135:1028-1035. https://doi.org/10.1016/j.foodc hem.2012.05.038

28. Roshanak S, Rahimmalek M, Goli SAH (2016) Evalation of seven different drying treatments in respect to total flavonoid, phenolic, vitamin C content, chlorophyll, antioxidant activity and color of green tea (Camellia sinensis or C. assamica) leaves. J 
Food Sci Technol 53(1):721-729. https://doi.org/10.1007/s1319 7-015-2030-x

29. Edziri H, Mastouri M, Cheraif I, Aouini M (2010) Chemical composition and antibacterial, antifungal and antioxidant activities of the flower oil of Retama raetam (Forssk.) Webb from Tunisia. Nat Prod Res 24:789-796. https://doi.org/10.1080/1478641080 2529190
30. Martins MDR, Arantes S, Candeias F, Tinoco MT, Cruz-Morais J (2014) Antioxidant, antimicrobial and toxicological properties of Schinus molle L. essential oils. J Ethnopharmacol 151:485-492. https://doi.org/10.1016/j.jep.2013.10.063

Publisher's Note Springer Nature remains neutral with regard to jurisdictional claims in published maps and institutional affiliations. 